\title{
Human Rights Violations in Kashmir
}

\author{
Zain Ul Abiden Malik ${ }^{1 *}$, He Zhilong ${ }^{2}$, Rafay Mubeen ${ }^{3}$ \\ ${ }^{1}$ Ph.DScholar, School of History and Civilization, Shaanxi Normal University Shaanxi, Xi'an, China, 7101192 \\ ${ }^{2}$ Professor, School of History and Civilization, Shaanxi Normal University Shaanxi, Xi'an, China, 7101192 \\ ${ }^{3}$ Masters in International Relations, University of Sargodha, Pakistan.
}

*Corresponding Author: Zain Ul Abiden Malik, Ph.DScholar, School of History and Civilization, Shaanxi Normal University Shaanxi, Xi'an, China, 7101192

\begin{abstract}
Since partition in 1947, the Kashmir is a problem between two nuclear nations, India and Pakistan. Both states cannot address the problem cordially. Indian armed forces have committed a massive violation of human rights, which is a matter of grave concern for Pakistan. So peace and stability can only be ensured in Kashmir if the Kashmiri Muslims are agreed to offer the right to self-determination. India and Pakistan have made bilateral attempts to recognize the Kashmir issue at different times. However, they have long been unable to resolve the issue bilaterally so that Kashmir's domestic viewers can be interested in negotiations, or the UN can play a constructive role by conducting a free and fair plebiscite. The study highlights Kashmiri people's fundamental human rights, the right to life, security, equality, and the right to self-determination.
\end{abstract}

Keywords: India-Pakistan, Human Rights, Violation, United Nations, Plebiscite, self-determination.

\section{INTRODUCTION}

Indian invasion of Jammu and Kashmir is illegal. The rest of the share was managed separately by Pakistan and China at a rate of 33\% and 22\% (Sankaran\&Sethi, 2003). Kashmir was split into four pieces by the October 1947 uprisings against Hari Singh's government, Jammu and Kashmir's last Dogra ruler, and the Indian interference in Kashmir.The Indian-Pakistani subcontinent borders with China and Afghanistan. The area is divided into five regions. Two regions managed by Pakistan are commonly known as Gilgit-Baltistan and Azad Jammu and Kashmir, while three are under the control of India and are incorporated by India into the state of Jammu and Kashmir, also known as the IHK. A control line that marks the ceasefire line between the areas managed by Pakistan and India both locally and on the map divides the controversial area in which India and Pakistan assert their respective claims. The geographical divisions of Kashmir do not make it a mere territorial dispute between the two historically rival states but also involve political underpinnings, cultural reflections, and economic discrepancies within and outside these divisions. The IHK is itself divided into three regions, which represent ethnic, religious, economic, and political diversities intensified during the recent years(Yaqoob, 2016).Multiple areas hamper both countries' progress owing to the Kashmir problem. Besides macro-level systemic destruction, the Kashmir problem has some micro-level consequences for both Pakistani and Indian citizens.The importance of the Indo-Pak relationship in international affairs has contributed to an interpretation of the issue for the Kashmir dispute, which is at the root of both countries' conflicts. (Malik \& Nawaz, 2014).

\section{KASHMIR ISSUE}

Due to varying ideologies and interests, there are different viewpoints regarding the Kashmir issue. The simple issue of the right to self-determination has become a progressiveclashconcerning India and Pakistan (Rizvi, 1994).With the creation of newterritories of India and Pakistan, British suzerainty over the 584(Korbel, 1966) princely states of the subcontinent ended in the light of the Indian Independence Act of 1947, according to partition scheme. The vital states known at that time as the princely states were free regard to their choice whether to join India or Pakistan as stated by the subcontinent's last British Viceroy in his policy statement that "prince states' rulers have an option to join one or another dominion in terms of both the state's geographical situation and public 
interests"(Mehmood, 1997).Pakistan and India were fighting three to four significant wars because of disagreements on this core issue.

Nevertheless, the Kashmir question should not be a cause for war between neighboring countries as it is a justifiable struggle of the Kashmiri people for fundamental right, the right to self-determination in the light to UN resolutions. This right was given to the citizens of 584 Principal States, but the citizens of Kashmir are denied until now in this modern age. "Nevertheless, it was the 2004 declaration released in Islamabad between President Pervaz Musharraff and Prime Minister Atal Behari Vajpayee that formed the basis for dialog between two countries in 2004-2007.

Pakistan and India had several meetings on different aspects of the Kashmir problem. They created a formula in principle for resolving the Kashmir dispute. These efforts received a significant setback with the terrorist attack in Bombay on November 26, 2008. This incident stopped the dialogue, and India blamed Pakistan for the terrorist attack, this under-mind their relation. A renewed effort for dialogue was made in 2011 and 2012, but they could not sustain the dialogue between 2013 and 2015. Indian attacks on the Line of Control and working boundary increased. With NarendraModi as Indian Prime Minister, the Hindu extremist Movement, and Ultra Nationalists have become very vocal in their criticism of Pakistan. Therefore as long as Prime Minister Modi policies do not change, there is hardly any chance of India and Pakistan dialogue. The Kashmir issue,therefore, remains unresolved" (Majeed, 2016). The region of South Asia is considered very critical concerning nuclear race because out of eight South Asian members; two members possess nuclear weapons. The most tensed thing for the world is that both of these two states are bitter enemies of each other. The bone of clashes between them is the issue of Kashmir that rose after the partition. There have fought several wars between these forces. The Kashmir issue is enlarging day by day. The stance of both of the states about Kashmir is not giving any solution. The Indian view of Kashmir, compared to Pakistan, is more racial and static. India considers Kashmir as an integral part of her, and Pakistan's point of view is also very high (Cheema, 1996).

Both the neighboring countries have fought several wars, and Kashmir was the primary reason behind the conflicts. If we take that point according to the partition plan, it is evident that Kashmir is Pakistan's part.Nevertheless, India needs to continue to dominate it at any expense by using its repressive strategy. India pursues a very rigid and oppressive policy on the Kashmir issue. Since the vast majority of the Kashmir Muslims, it was clear that the Kashmir state would join with Pakistan. The key reason behind the partition was the Two Nations theory that motivated subcontinent Muslims to get themselves a separate homeland where they could easily lead their lives according to Islam.Even the Hindus and some Muslims dismissed the concept of the two-nation theory when making the Indian National Congress the sole political body of India as a whole. The Muslims of Pakistan, as well as of Kashmir, consider that without annexing Kashmir with Pakistan, the partition is incomplete because it is the violation of the two-nation theory that was the main reason for partition (Basrur, 2008).The Indian hegemonic regional opinion concerning its neighbors and contextual framework of neutralization of dominant classes resulted in increased centralized power in domestic politics with growing international influence. Religious character, ethnic diversities, and incomplete nation-building hasgreat influences on Indian foreign policy (James \&Ozdamar, 2005).

\section{INDIA'S KASHMIR STATUS}

As most Pakistanis and Kashmiris see it as an unfinished program on the subcontinent, it appears to be a matter of pride for India to retain its claim to secularism.Most Indian leaders now believe that "Kashmir is an integral part of India" while referring to Kashmir's fake instrument of accession with Indian dominion made by Maharaja. A well-known scholar Alaster Lamb believed that India and Kashmir had not signed an instrument of accession (Kazmi, 2009).India sought to mark the Kashmiri people's indigenous movement with a holy war between Muslims and Hindus waged by Muslim fundamentalists in order to attain Western sympathy. India has sought to portray the movement as a Pakistan-sponsored terrorist operation (Qadir, 1994).

India has followed a rigorous Kashmir policy. She is using different strategies to occupy Kashmir. Every terrorist attack in India is blamed as Pakistan and the mujahedeen in order to maintain her shrewd face behind it. However, the real picture is something else. India is the main sponsor to activate terrorist activities in Pakistan. A few years back, Pakistan arrested a RAW agent in 
Baluchistan who admitted that the intelligence agency of India is sponsoring terrorism in different parts of Pakistan. India also held Pakistan responsible for the 2001 attacks on the Indian parliament (Hashmi\&Sajid, 2017). The strategic location of Kashmir is vital for India as it gives route to the Central Asian States. It also provides an essential location for India against Pakistan and China. Siachen Glacier is the main boundary between India and China. She knows that if she lost Kashmir, she would be at the direct target of Pakistan and China (Kalis\& Dar, 2013) India considered Kashmir as its integral part of unified India and never wanted to change the status even by any resolutions of the United Nations. They are not ready to discuss the Kashmir issue even in better bilateral relations talks. If Pakistan desire to hold talks on this issue,the only negotiation will be made about Pakistan administered Kashmir territory. Indian popular perspective is that Pakistan should include insurgent activities in Kashmir for good relations and to hold talks. The only solution in the Indian view is that Indian administered Kashmir territory is an integral part of India and Pakistan should accept it. They will never go for the ways of losing this territory or its complete independence options. (Gondal, 1999)

\section{Pakistan's Kashmir Status}

Pakistan, for the bulk of Kashmir's population, is Muslim. India has no substantial justification for claiming the Kashmir. India uses a coordinated media strategy to show Kashmir its integral part (Basrur, 2008). All Pakistani and Kashmiri leaders have declared Kashmir's accession as the biggest 20th-century scam. Pakistani leaders view Kashmir as an incompleteplan of subcontinent partition, a lifeline, and a jugular vein due to the region's geographical significance and religious ties between people from both regions. The government and people of Pakistan are committed to providing social, administrative, financial, and diplomatic support to the citizens of Jammu and Kashmir, who are always struggling to reach their final destination (Mehmood, 2015). This is an old Indian tactic to blame Pakistan for supporting the Kashmiri people's struggle to cover up brutal Indian power's actions. India is blamable for the nastiest abuses of human rights and state terrorism in Kashmir. This is Indian's strategy of deceit to deceive the world and attain the international community's support for continuing its subjugation in the Indian Kashmir keeping (Pervez, 2013).

Indian forces are responsible for reporting brutalities on the citizens of Kashmir, but the global community is silent though considering the issue as bilateral due to close relations between India and the United States.The Indian government made effective and tactful use of the instrument of diplomacy.As a result, India remained very successful in gaining support for its position on Kashmir at an international level.At the same time, nearly all study reports indicated that without solving unresolved problems between two nuclear powers, there could be no stability and prosperity in the region (Fayaz, 2016). The Kashmir issue is the major issue of Pakistan-India bilateral relations. Both of the countries are spending a vast amount of their budgets on defense. Both of them are increasing their arms. They have begun another war of arms race as they are enhancing their defense capabilities day by day.

However, on the other hand, the masses of both countries are facing various problems. A considerable portion of the population of both countries is living below the poverty line. The condition is worse in India than in Pakistan. They have fought several wars, and most of them are due to Kashmir (Gondal, 1999).

As India and Pakistan both have nuclear powers so it will work as a deterrence strategy that will stop them from engaging any war in the future. Both of them know that they are equal in power, and the outbreak of war will be so terrible (Mahmood, 1998). However,some analysts hold that it may break a nuclear war in South Asia. The issue of Kashmir is very deep-rooted between Pakistan and India that may become the reason for another war. This war will not be simple as it is before rather it will be a nuclear war that will become a reason for massive destruction (Spector, 1990)

\section{HUMAN RightS Violations IN KASHMIR}

This is an old Indian tactic to blame Pakistan for supporting the Kashmiri people's struggle to cover up brutal Indian power's actions.In Kashmir, India is blamed for the worst abuses of human rights and State terrorism. This is Indian's strategy of deceit to deceive the world and attain the international community's support for continuing its repression in the Indian Kashmir keeping (Pervez, 2013).In response to Indian propaganda, Pakistan dismissed India's view and strongly denounced the worst 
abuses of human rights in the light of numerous studies released by world-renowned human rights organizations, such as Human Rights, Asia Watch and Amnesty International (Human rights Asia watch 1990-1998 and Amnesty International Reports, 1990-1998).In August, the government abolished Jammu and Kashmir's special constitutional status and divided the state into two independent territories ruled by federal governments. The government deployed additional troops to the area before announcing the decision, shut down the internet and phones, and put thousands of people in preventive detention, including elected officials, triggering international condemnation.Meanwhile, a citizenship verification project in the northeastern state of Assam removed nearly two million people, mainly of Bengali ethnicity, many of whom were Muslims, and placed them at risk of statelessness (John, 2019).

So, India has posed curfew from August 5, 2019, in Kashmir valley. Kashmir is presenting the biggest sub-jail in the world. Indian forces are violating human rights as well as women's rights. They are deprived of their basic fundamental rights.Kashmiri freedom fighters are fighting a Holy war of their right for self-determination against the Indian government for the last seven decades. The Indian policy of crushing this movement is at the peak, and they are saying openly that they never accepted the partition of the subcontinent with the two-nation theory and will never accept in future (Bashir, 2005). A large proportion of the army is deployed in Kashmir by India. The laws that have been implemented by India in Kashmir are also violating human rights as well as international law. The Kashmiri women are being raped by the Indian army. Thousands of people have been killed by the brutal Indian army. India has deployed over 700, 000 forces in Indian occupied Kashmir. There have been held many rounds of talks between Pakistan and India but all in vain. India is not ready to have smooth talks with Pakistan over the issue of Kashmir because she knows that the smooth solution can occur only if a referendum is held in Kashmir to know about the perception of the people of Kashmir. On one side, India is refusing all types of the solution, and on the other hand, she is deploying more and more personnel in Indian occupied Kashmir to maintain its forceful stay there. In order to crush the freedom movement of the Kashmiris, the Indian army is using many brutal and human violating measures. In the past few years, thousands of women, men, and innocent children have been killed. (Majid, 2016) Human rights violations in Indian occupied Kashmir is one of the major hindrances in the peacebuilding process, and people in Pakistan and the world are concerned regarding the violations of human rights in the area. The provision of the basic rights for the people in the area is pathetic, and international organizations have many times highlighted the issue (Aggarwal, 1999).

\section{Great Powers FunCtion}

Tashkent Declaration was signed by USSR mediation. Simla Accord was signed in 1972 between Indra Gandhi and Z.A. Bhutto. Certain agreements were made long ago but are to be revisited, refreshed, and reiterated to keep these workable, tangible, and fruitful for the nations for which they exist (Chawla, 2013).The great powers are playing an unjustified role in the policy of equilibrium for Pakistan and India. Most of them are favoring the Indian point of view. India is enhancing its nuclear arsenal with the help of great powers that is a threat to inspire Pakistan also to enhance its nuclear capabilities. However, on the other side, Pakistan is victimized by the criticism of great powers (Khan, 2011). The use of rape and other such cruelty has been reported by many organizations and media agencies. There have been almost 100 reported cases of rape in detention by the Indian forces; however, the actual numbers are very higher than that as Muslim women are less likely to report such issues. Due to the deployment of heavy forces in Indian occupied Kashmir, the international organizations of human rights are not allowed to enter in that part because the entrance of the international organization will reveal the hidden cruel face of India. Amnesty International is an important international organization that works for human rights. This organization was also banned for many years to work in Kashmir (Javaid, 2018). Pakistan always highlights the worse on-going situation in held Kashmir and always urges the international community and the UN to take notice of the human rights violations in Kashmir and push India to immediately put an end to atrocities against Kashmiris and resolve the Kashmir dispute following the UN resolutions but unfortunately very few voices have come out against the Indian tyranny. Several efforts were made to address disputes through bilateral, multilateral talks and UN mediation. The history of agreements between India and Pakistan is started from Liaquat-Nehru Pact. When the Kashmir issue referred to the UN, internal players tried their role in conflict resolution through bilateral talks and United Nations mediation. In 1960 Indus Water Treaty was signed partly due to the role of the UN and partly due to the World 
Bank (Arif, 2011). Changes concerning US Policy on the Kashmir issue require understanding the geopolitical context of dispute and should look for minimum promises to divert the peaceful resolution towards the maximum potential of conflict resolution. Washington must support open border trade, human rights protection, and autonomy among the two states (Wirsing, 2005). Certain tangible solutions might be frequent follow-ups of the meetings enabling the nations to review the verdict in the light of changing scenarios. It is also urged that the big powers should play their positive roles in helping the nations to come out of the turmoil till the talks are free, fair, and bilaterally aligned (Arif, 2011).

\section{THE ROLE OF THE UN SECURITY COUNCIL}

"India tried to make this imperialistic occupation perpetually by force instead of winning their hearts and minds. Pakistan demanded the withdrawal of Indian forces from Kashmir and plebiscite under the joint control of both the governments, but India did not agree. The Kashmiris retaliated with the moral and military help of Pakistan. When the Indian advance met with reverses, she went to the Security Council on January 1, 1948. The Security Council appointed the United Nations Commissions on India and Pakistan (UNCIP) to examine the Kashmir issue and suggest ways to settle it"(Javaid, 2018). The whole of the above discussion shows that the issue of Kashmir has become a very critical concern for the security of South Asia. This issue must be solved as soon as possible. Otherwise, it will create so many other issues in South Asia. The nuclearisation of both countries is attached to this territorial issue. To eradicate the chances of nuclear war between Pakistan and India, the issue of Kashmir must be solved through table talks. There are some ways to solve this issue smoothly. These are the following. The first important way to solve the issue of Kashmir is the proposal of the United Nations Security Council (UNSC) ought to be followed. A referendum should be held in Kashmir to know the wishes of the Kashmiri people to which country they want to affiliate. However, India, who brought this issue to the UN, is refusing to follow the way provided by UNSC (Chaudhry, 19961997). The nuclear attack on Hiroshima and Nagasaki bewildered the world about the first-ever use of nuclear technology. It inspired the USSR, the major opponent of the US, to work on the formation of nuclear weapons. After the US, USSR became the second nuclear-weapon state in 1957 that further inspired the big powers of the world to acquire this technology. One by one, all of the permanent member states of the UN Security Council got nuclear power sooner or later. The story of the race of nuclear arms does not end here; rather, it further gave way to other prominent states to get this deadly technology. At last, this race came to South Asia in 1974 when India executed her first explosions while misbalancing the power of South Asia with Pakistan. India started to work on nuclear power after being defeated by China in the Sino-Indian war of 1962. Pakistan started to work on nuclear arms after the Indo-Pak war of 1971 (Mazhar\&Goraya, 2016).

\section{Global Media's Roles}

The role of the media cannot be neglected in shaping public opinion. It is used as anessential tool to prepare any propaganda about any issue. The media has become so famous today that it can represent the wrong thing in the right way. However, it is the duty and media ethics to inform the people in the right way. Media can be used as a tool to normalize the tension between these competing forces. It can use a preventive, constructive, and active role in the prevention of conflict over the Kashmir issue. If the media uses a fair policy while exploring the real picture behind the story, this issue will no longer prevail in the mutual ties. The role of media is also may be perceived as a mediator between these forces (Manoff, 1997). South Asia is also surrounded by so many issues. This region is also facing many territorial and bilateral issues that are creating so many hurdles in the progress of this region. South Asia includes eight countries Pakistan, India, Sri Lanka, Bangladesh, Nepal, Bhutan, Maldives, and Afghanistan. Out of all these South Asian members, Pakistan and India are considered two crucial countries because they have nuclear powers. They are also considered each other enemies since they have not stable relations. On the other hand, they have a long history of their bilateral clashes. The main issue between both of the countries is the Kashmir issue. This issue has enlarged so much that the foreign policies of both countries have a special place in this issue. The role of media is also very critical about this issue. The media is employing different policies in both of the countries while representing the concerning state on the right. Kashmir dispute is an untold story of a confrontation between Pakistan and India. Both countries are fighting each other forthe last seven decades. Due to their wrong policies, the Kashmiri people are facing many miseries. They are being 
treated brutally in Kashmir by India. It has become the most stubborn problem between Pakistan and India (Kochler, 2008). The role of global media is also vital in handling the Kashmir issue. Notably, the US media is a prominent figure in South Asia. Both of the states have historical relations with the US so that this issue may be resolved through the intervention of American media. The role of America is always welcomed by Pakistan about the Kashmir issue. Being the superpower of the world, the US has to force India to change its policy about Kashmir. However, unfortunately, the US is also not paying attention to this issue. Instead, she is also favoring the stance of India on Kashmir. The reason behind this scene is that Pakistan has very stable relations with China that is the sign of apprehension for India as well as the US. China is a direct threat to India and the US due to its strengthening economy (Javaid, 2018).

\section{CONCLUSION}

Overall, it is concluded that the Kashmir issue has become a very concern issue. The Kashmir issue has become South Asia's most critical question. Although this issue has a long history between Pakistan and India, after 1998, the situation changed marvelously, as each of the states concerned demonstrated their nuclear capabilities.India is currently busy strengthening its military capabilities. This problem needs to be resolved by Pakistan and India Consensus. The bilateral and global media will play their part in addressing this question of conflict. To remove the global conflict, the media must follow Peace Journalism's strategy.India and Pakistan have nuclear power, and they can demonstrate mutual tolerance. India is regarded as the world's largest democracy, so Indian government must adopt a democratic approach to the Kashmir issue.Eliminating this issue will bring prosperity to this region; otherwise, the future of these two countries is not as bright as this. It is not just a problem for the entire world rather than for South Asia. Multiple round talks have been held between both countries but all in vain.

The role of great powers is also very critical in solving this issue not only of territorial but also of religion and ethnicity. However, the position of the great powers, particularly of the US, is unfortunately not encouraging. The current article exposes the background to the Kashmir issue, as well as the Kashmir issue's religious and ethnic origins.So, for 70 years, the Kashmir issue continues to seek the attention of global powers for resolution. Full support and the vibrant role played by the international community are considered crucial to resolving the Kashmir issue, which the Kashmiri people do not have for their just cause.UNSC has adopted several resolutions to hold a plebiscite for the Kashmiri people's self-determination, but it is not obliged to enforce Security Council resolutions and has not played a significant role in resolving the conflict. Musharraf met Vajpai at the SAARC summit in 1994 and resumed talks on Kashmir. He provided a solution to the Kashmir conflict by establishing joint Indian, Pakistani, and Kashmiri administration in Kashmir. All his efforts proved fruitless due to the 2007 Samjhutta Express explosion and the 2008 Mumbai attack.Today, this bilateral issue is not pictured as it was before the 1971 war. The two countries did not have nuclear power at the time. The condition of those countries' bilateral relations is getting worse. Both of them now have nuclear weapons that can alter world geography in a few seconds. Though having nuclear power is not perfect, there are still several advantages to these weapons. It established a terror balance between them, which prevented them from engaging in any further wars.

\section{REFERENCES}

[1] Aggarwal, H. (1999). Human Rights. Allahabad: Central Law Publication

[2] Arif, Muhammad, (2011). Pakistan Bharat Relations: Changing Trends in 21st Century, Centre for South Asian Studies, University of the Punjab, Lahore.

[3] Bashir, M. A. (2005). India's Human Rights Track-record. In M. A. Bashir, \& K. S. Haider, The Kashmir Imbroglio: Looking Towards the Future. Islamabad: Islamad Policy Research Institute.

[4] Basrur, R. M. (2008). The State at the War in South Asia. London: University of Nebraska Press.

[5] Chawla, M. Iqbal, (2016). Can the Principle of Coexistence between India and Pakistan Help to Achieve Peace and Prosperity in the Region.Journal of Research Society of Pakistan.Vol 53 No. 2. P. 219-226.

[6] Cheema, P. I. (1996). Nuclear Developments in Pakistan, Colombo: Regional Centre for Strategic Studies.

[7] Fayaz, Sadia. (2016) Kashmir Dispute between Pakistan and India: The Way Out. The Dialogue, Vol. XI. No. (1), 6582.

[8] Gondal, T. M. (1999).Kashmir in a Nuclear Subcontinent.Settling the Kashmir Issue. Islamabad: Institute of Regional Studies. 
[9] Hashmi, R. S., \&Sajid, A. (2017). Kashmir Conflict: The Nationalistic Perspective (A Pre-Partition Phenomenon). Journal of South Asian Studies, 32(1), 219-233.

[10] James, C. C., \&Ozdamar, O. (2005). Religion as a Factor in Ethnic Conflict: Kashmir and Indian Foreign Policy. Terrorism and Political Violence, 17, 447-467.

[11] Javaid, U. (2016). Security Concerns in South Asia. Lahore: Centre for South Asian Studies.p.56.

[12] Kazmi, M R. (2009).A Concise History of Pakistan. Karachi: Oxford University Press.

[13] Khan, Z. (2011).Nuclear Pakistan: Strategic Dimensions. Karachi: Oxford University Press.

[14] Kochler, H. (2008). The Kashmir Problem between Law and Real Politics.Indo-Pak Changing Perceptions on Kashmir. Brussels: International Progress Organization.

[15] Mahmood, A. (1998, May). After Nuclear Stand-Off. The Dawn.

[16] Majid, A. (2016). Kashmir A Conflict between India and Pakistan.South Asian Studies, 31 (01), 153.

[17] Malik, Z. U. A., \& Nawaz, A. (2014). Kashmir Conflict and Foreign Policy of Pakistan. International Journal Humanities and Social Sciences, 3(5), 179-188.

[18] Majid, A., \& Hussain, M. (2016). Kashmir: A Conflict between India and Pakistan. Journal of South Asian Studies, XXXI (1), 149-159.

[19] Manoff, R. K. (1997). The Media's Role in Preventing and Moderating Conflict.Virtual Diplomacy Conference.Washington, D.C. Institute of Peace.

[20] Mazhar, M. S., \&Goraya, N. S. (2016). South Asian Nuclear Security or Deterrence: An Analysis. Journal of Political Studies, 23-1.

[21] Mehmood, Irshad. (1997). Masla Kashmir keImkani Hal. Islamabad: Institute of Policy Studies.

[22] Mehmood, SardarSajid. (2015). Facts of Accession and Indian Intervention in Kashmir. Muzaffarabad: JKLC.p.76.

[23] Pervez, Muhammad Shoaib, (2013). Security Community in South Asia: India-Pakistan, London: Rutledge Press.

[24] Qadir, Shah Ghulam. (1994). International Effort to Solve Kashmir Issue (ed.) Perspectives on Kashmir by Dr. Kaniz Fatima Yousaf, Islamabad: Pakistan Forum.

[25] Sankaran, Vivek\&RamitSethi, (2003). India, Pakistan, and the Kashmir Conflict: towards a Lasting Solution. Ethics of Development in a Global Environment Term Paper.

[26] Spector, L. (1990, Feburary ). The Nuclear Edge .Wshington : Washington Post.

[27] Wirsing, D. R. (2005). The United States and Kashmir: How (\& How not) to Promote Peaceful Resolution of the India Pakistan Conflict. In P. I. Cheema, \& M. H. Nuri, The Kashmir Imbroglio. Islamabad: Islamad Policy Research Institute

[28] Yaqoob, A. (2016). India-Pakistan Confrontation: What Has Changed About Indian-Held Kashmir Since 1947? Institute of Regional Studies.

Citation: Zain Ul Abiden Malik, et.al. "Human Rights Violations in Kashmir” International Journal of Political Science (IJPS), vol 6, no.2, 2020, pp. 17-23. doi: http://dx.doi.org/10.20431/2454-9452.0602003.

Copyright: (c) 2020 Authors. This is an open-access article distributed under the terms of the Creative Commons Attribution License, which permits unrestricted use, distribution, and reproduction in any medium, provided the original author and source are credited. 